\section{Call for nominations for new members of the International Commission on Zoological Nomenclature}

The following members of the Commission reach the end of their terms of service at the close of the XXV General Assembly of the International Union of Biological Sciences to be held in Paris in September 1994: Dr F. M. Bayer (U.S.A., Corallia); Professor J. O. Corliss (U.S.A., Protista); Professor Dr G. Hahn (Germany, Trilobita); Professor Dr O. Halvorsen (Norway, Parasitology); Dr Ya. I. Starobogatov (Russia, Mollusca); Dr V.A. Trjapitzin (Russia, Hymenoptera).

The addresses and specialist fields of the present members of the Commission may be found in the Bulletin of Zoological Nomenclature, 50 (1) (March 1993). Under Article 3b of the Commission's Constitution a member whose term of service has ended is not eligible for immediate re-election unless the Council of the Commission has decided to the contrary.

The Commission invites nominations, by any person or institution, of candidates for membership. Article $2 b$ of the Constitution prescribes that: 'The members of the Commission shall be eminent scientists, irrespective of nationality, with a distinguished record in any branch of zoology who are known to have an interest in zoological nomenclature'. (It should be noted that 'zoology' here includes the applied biological sciences (medicine, agriculture, etc.) which use zoological names.)

Nominations made since June 1990 will be reconsidered automatically and need not be repeated. Additional nominations, giving the date of birth, nationality and qualifications (by the criteria mentioned above) of each candidate should be sent by 1 June 1994 to: The Executive Secretary, International Commission on Zoological Nomenclature, c/o The Natural History Museum, Cromwell Road, London SW7 5BD, UK.

The International Commission on Zoological Nomenclature has received the following Applications, which were published recently in the Bulletin of Zoological Nomenclature. Comment or advice on them is invited for publication in the Bulletin, and should be sent to the Executive Secretary, ICZN, c/o The Natural History Museum, Cromwell Road, London SW7 5BD, UK.

Case 2882. Lagomeryx Roger, 1904 (Mammalia, Artio- dactyla): proposed designation of $L$. ruetimeyeri Thenius, 1948 as the type species.

Abstract. The purpose of this application is to conserve the established understanding of the name Lagomeryx Roger, 1904 which has been used for nearly 90 years for a genus of Eurasian Miocene cervoids. The present type designation is of a species of uncertain identity which renders Lagomeryx either a senior or a junior subjective synonym. It is proposed that Lagomeryx ruetimeyeri Thenius, 1948 be designated the type species, thereby also allowing the stable usage of generic names of other Miocene cervoids to be maintained.

Case 2883. Procervulus Gaudry, 1877 (Mammalia, Artiodactyla): proposed designation of Antilope dichotoma Gervais, 1849 as the type species.

Abstract. The purpose of this application is to conserve the current understanding of the name Procervulus Gaudry, 1877 which is in established usage for a genus of Miocene cervoids. It is probable that Gaudry misidentified the single species that he included in the genus. It is proposed that Antilope dichotoma Gervais, 1849 be designated the type species, thereby also maintaining the usage of other names of distinct Miocene cervoid genera.

The following Opinions were published recently in the Bulletin of Zoological Nomenclature.

Opinion 1720. Cycloceras M'Coy, 1844 (Mollusca, Nautiloidea): C. laevigatum M'Coy, 1844 designated as the type species, and a neotype designated for C. laevigatum.

Opinion 1721. BELEMnitidae Owen, 1838 (Mollusca, Coleoidea): ruled to be unavailable; Belemnites Lamarck, 1799 and B. paxillosa Lamarck, 1801 suppressed.

Opinion 1730. Graptolithus clintonensis (currently Monograptus clintonensis; Graptolithina): specific name attributed to Hall, 1852 and a lectotype designated.

Opinion 1731. Monograptus crenulatus (currently Monoclimacis crenulata; Graptolithina): specific name attributed to Elles \& Wood, 1911, and a lectotype designated.

Opinion 1734. Ichthyosaurus trigonus Owen, 1840 (currently Macropterygius trigonus; Reptilia, Ichthyopterygia): neotype replaced by rediscovered holotype. 